\title{
Pre-service Teachers' Opinions about the Use of 21st Century Learner and 21st Century Teacher Skills
}

\author{
Canses Tican * \\ Mugla Sitki Kocman University, TURKEY
}

\author{
Sabahattin Deniz \\ Mugla Sitki Kocman University, TURKEY
}

Received: November 8, 2018 - Revised: December 22, 2018 - Accepted: December 25, 2018

\begin{abstract}
The purpose of the current study is to determine pre-service teachers' opinions about 21st century learner and teacher skills. The study group of the current research is comprised of 391 senior students from an education faculty. As the data collection tool, the 21st century Learner Skills Use Questionnaire and 21st Century Teacher Skills Use Questionnaire were employed. In the analysis of the collected data, frequencies, percentages, arithmetic means, independent samples t-Test, One-Way Anova, Correlation, Mann Whitney-U, Kruskal Wallis techniques were used. The findings of the study revealed that the pre-service teachers' opinions about 21 st century learner and teacher skills vary significantly depending on the variables of gender, department attended, academic achievement, experience of private tutoring and practicum teaching (doing practicum teaching at elementary and secondary schools). As a result, it was concluded that the pre-service teachers are ready for using 21st century learner skills (cognitive skills, autonomous skills, collaboration and flexibility skills, innovativeness skills) and teacher skills (administrative skills, technopedagogical skills, affirmative skills, flexible teaching skills, generative skills). However, it was also found that the pre-service teachers were not able to make enough use of learner and teacher skills during their practicum teaching at schools. Moreover, a positive, medium and significant correlation was found between 21st century learner skills and 21st century teacher skills.
\end{abstract}

Keywords: 21st century learner skills, 21st century teacher skills, pre-service teachers, teacher training, teaching and learning.

To cite this article: Tican, C., \& Deniz, S. (2019). Pre-service teachers' opinions about the use of 21st century learner and 21st century teacher skills. European Journal of Educational Research, 8(1), 181-197. doi: 10.12973/eu-jer.8.1.181

\section{Introduction}

The skills needed by people in the $21^{\text {st }}$ century in terms of professional life, citizenship and self-actualization are highly different from the ones needed in the $20^{\text {th }}$ century. Adaptation of people having spent much of their life in the $20^{\text {th }}$ century to the $21^{\text {st }}$ century can be challenging as the skills of the $20^{\text {th }}$ century are different from those of the $21^{\text {st }}$ century and new information and communication technologies have emerged in the $21^{\text {st }}$ century. For example, the work done by people, as opposed to the work done by machines, constantly changes as computers and telecommunications develop (Dede, 2009). Preparation of the students of the 21st century for adaptation to professional life, social values and life itself is a complicated task. Globalization, technology, migration, international competition, changing markets and international environmental and political changes add a new urgency to the acquisition of the skills and knowledge needed by students to be successful in the $21^{\text {st }}$ century (Saavedra and Opfer, 2012a). Howard Gardner states that children should now be equipped with the knowledge and skills to do the works that cannot be done by machines. This also clearly indicates the importance of $21^{\text {st }}$ century skills. Skills such as creativity, critical thinking, problem solving and cooperation will constitute some kind of "universal literacy" needed to survive in the $21^{\text {st }}$ century (Akgunduz et al., 2015).

Many nations in the world have been conducting comprehensive reforms in their curricula, instruction and assessment to prepare children better for the living and working conditions and higher education in the $21^{\text {st }}$ century (Schleicher, 2012). Many countries have begun to reform the mission statements of their education systems as a result of international benchmarks (e.g. PISA) (Häkkinen et al., 2017).

In the United States, a consortium of teachers, education experts and CEOs of the technological companies preoccupied with the occupations of future prepared a framework report entitled as " $21^{\text {st }}$ century skills" in 2011 . This framework sets out what knowledge, skills and competencies students will need to be successful in their future business life and to become a model citizen in a democratic system. In the US, the educational community and business circles highly appreciated the report of $21^{\text {st }}$ century skills framework and called for schools to equip their students with qualifications

\footnotetext{
* Corresponding author:

Canses Tican, Mugla Sitki Kocman University, Faculty of Education, Turkey.

$\triangle$ ctican@hotmail.com
} 
such as problem solving, creativity, innovation, critical thinking, information and communication technology literacy, so that they can be prepared for the business world of future (Aydeniz, 2017).

In our country, curriculums were renewed by the Ministry of National Education in 2017. Competencies and skills called as $21^{\text {st }}$ century skills have been incorporated to these renewed curriculums. In this regard, the skills to be needed by students to be personally, socially, academically and professionally successful at both national and international level have been defined in the Turkish Competencies Framework (TYC). TYC defines eight key competencies. The competencies and skills to be imparted to students by the curriculums are as follows: (1) Communication in the mother tongue, (2) communication in foreign languages, (3) mathematical competency and basic science/technology competencies, (4) digital competency, (5) learning how to learn, (6) social and citizenship-related competencies, (7) taking initiative and entrepreneurship, (8) cultural awareness and expression (MEB, 2017a).

Moreover, the Ministry of National Education initiated the Project of Increasing Opportunities and Improving Technology "FATIH" in 2010 in order to provide equality of opportunity in education and instruction and to make more effective use of information technologies in order to enhance technological opportunities in learning-teaching process in such a way as to activate more senses (MEB, 2018). Eryllmaz and Uluyol (2015) stated that the FATIH project targeting the integration of information technologies into learning-teaching process is directly associated with some of $21^{\text {st }}$ century skills such as information, media and technology skills. With all transformations and changes in education, learner characteristics and teacher characteristics have changed. Teachers need to teach $21^{\text {st }}$ century skills to their students for them to survive in the $21^{\text {st }}$ century. Teachers should first have these skills and should know the ways to effectively impart them to their students.

Voogt, Erstad, Dede and Mishra (2013) argue that not only students but also teachers must acquire $21^{\text {st }}$ century skills and teachers should be qualified enough to support the development of 21st century skills. According to Valtonen et al. (2017), teachers are expected to be familiar with the various pedagogical approaches and appropriate ways to make use of information and communication technologies in promoting the development of their students' 21 st century skills. According to Valli, Perkkilä and Valli (2014), teachers should have adequate understanding of the development and implementation of $21^{\text {st }}$ century skills. Teacher training, which has an important role in the training of the teachers of future, plays an important role in the inculcation of knowledge and competencies required for the acquisition of these skills by teachers.

In our country, the institution primarily responsible for the training of pre-service teachers is education faculties. In these faculties, while induction training is given to pre-service teachers to prepare them for the profession on the one hand, academic discussions about education have been conducted on the other (YOK, 2018). Education faculties should be able to train their students in such a way as to teach in the technopedagogical classes of the $21^{\text {st }}$ century. In this context, $21^{\text {st }}$ century skills should be incorporated into teacher training programs. In the literature, these skills are addressed as follows:

\section{Literature Review}

\section{$21^{\text {st }}$ Century Learner Skills}

All of the international research and educational planners and theoreticians involved in the field of education have attempted to develop frameworks necessary for students to be successful in the information-based and technologydirected global society under the concept of " $21^{\text {st }}$ century skills" (Cretu, 2017). In the literature, there is no universal agreement on what $21^{\text {st }}$ century skills are. In the literature, there are different classifications of these skills. For more effective education and instruction, it is of great importance to know what $21^{\text {st }}$ century learner skills are. According to Trilling and Fadel (2009), in the studies conducted within the context of Partnership21 (P21, 2015), 21 st learner skills are subsumed under three headings, being "learning and innovativeness skills", "information, media and technology skills", "life and career skills".

Wagner (2008) named 21st century skills to be possessed by $21^{\text {st }}$ century learners as "survival skills" and gathered them under seven headings; "critical thinking and problem solving", "cooperation between networks and leadership through effect", "agility and adaptation", "initiative and entrepreneurship", "effective verbal and written communication", "having access to and analyzing information" and "curiosity and imaginative power". According to the standards of American Association of School Librarians (AASL), besides technology, great importance should be attached to face-to-face sharing of knowledge (Orhan-Goksun and Kurt, 2017). The AASL (2009) standards have been defined as "questioning, critical thinking and information acquisition", "reaching conclusions, making informed decisions, applying the existing knowledge into new situations and creating new information", "sharing information and demonstrating ethical and productive participation as the members of a democratic society" and "pursuing personal and aesthetic development". In a project by OECD, Pedro (2006) identified the characteristics of new millennium learners as "alternative cognitive skills", "changes in cultural practices and social values" and "expectations for teaching and learning". 


\section{$21^{\text {st }}$ Century Teacher Skills}

Today, problem solving, communication, cooperation, teamwork, critical thinking, creative thinking, using information and communication technologies come to the fore as $21^{\text {st }}$ skills to be acquired by students. In order to impart these skills to students, the teacher of the $21^{\text {st }}$ century should be able to have skills and competencies such as continuous development, empathy, effective communication, problem solving, sample personality demonstration and guidance. Teachers who train learners of the $21^{\text {st }}$ century should be able to apply $21^{\text {st }}$ century learner skills in their in-class activities. Saavedra and Opfer (2012b) defined the skills to be possessed by $21^{\text {st }}$ century teachers as making it relevant, teaching through disciplines, promoting thinking skills, encouraging the transmission of learning, teaching students how to learn, directly addressing misunderstandings, treating team work as an outcome, making use of technologies to reinforce learning and nurturing creativity.

Within the scope of general teacher competencies, the qualifications and competencies to be possessed by teachers are determined by the Ministry of National Education. The first official works on teacher competencies started in 1999. Answers to the questions such as "What should the qualifications of teaching be in the $21^{\text {st }}$ century?", "What qualifications do we want from our teachers and students?" etc.... have been sought. In this way, the general competencies of the profession of teaching have been determined as 6 main areas of competencies; "personal and professional values-professional development", "knowing students", "learning and teaching process", "monitoring and evaluating learning and development", "school-family and society relationships" and "program and content knowledge", under which 31 sub-competencies and 233 performance indicators have been defined. It was published in 2006 in the Journal of Communiqués No. 2590 and entered into force. General teacher competencies of teaching profession were updated in 2017. General competencies of teaching profession are made up of 3 main areas of competencies related to each other and complementing each other, 11 sub-competencies and 65 indicators related to these competencies (MEB, 2017b). The International Society for Technology in Education (ISTE) standards and the National Educational Technology Standards (NETS) developed within the context of a project directed to training of the teachers of future have been adopted as a guide in the use of educational technologies in many countries as well as in our country. Though competencies in using educational technologies to be demonstrated by teachers have been updated in different years, they first emerged as 13 indicators with the name of NETS in 1993. They were last updated in 2008 to form five areas of competencies and to include four performance indicators under each area of competencies (Orhan, Kurt, Ozan, Som Vural and Turkan, 2014). These standards have been defined as "facilitating students' learning and creativity and inspiring", "designing and developing the experiences and evaluations of the digital age", "developing models for digital age working and learning", "promotion of digital citizenship and responsibility and creating models for them" and "attending to professional development and leadership" (ISTE Standards-T, 2008). The name of these standards was changed to "ISTE standards for teachers" in 2015 (ISTE, 2018).

As a response to the question "How to become a good teacher?", Melvin (2011) developed performance standards for teachers. These standards are "preparing the environment for the change", "organizing physical environment and materials", "reflective instructional model", "being a model as a leader", "doing practices in breaks", "working with parents", "building the sense of citizenship in students" and "constructing a permanent learning environment". Lemov (2010) collected 49 techniques that could be used for effective instruction under seven headings. These headings are; "generating high academic expectations", "making planning to ensure academic achievement", "construction and delivery of lessons", "making students interested in your lessons", "creating a strong classroom culture", "generating high behavioral expectations and maintaining these expectations" and "building personality and trust".

When the national literature is reviewed, the studies conducted by Coklar (2008); Daghan, Nuhoglu Kibar, Menzi Cetin, Telli and Akkoyunlu (2017); Orhan-Goksun (2016); Sural (2017); Sahin (2010) on 21 st learner and teacher skills of preservice teachers come to the fore. This amount of research seems to be inadequate. Thus, the current study is believed to make contribution to the literature. In this regard, answers to the following questions were sought:

1. Do the pre-service teachers' use of $21^{\text {st }}$ century learner skills and $21^{\text {st }}$ century teacher skills vary significantly depending on;
a. Gender,
b. Department (branch),
c. Academic achievement,
d. Experience of private tutoring,
e. Experience of using learner skills during their practicum teaching,
f. Experience of using teacher skills during their practicum teaching?

2. Is there a significant correlation between the pre-service teachers' $21^{\text {st }}$ century learner skills and $21^{\text {st }}$ century teacher skills? 


\section{Methodology}

\section{Research Model}

The current study employed a model built on the relational survey and causal comparison designs. The relational survey models are research models aiming to determine the existence and/or degree of a correlation between two or more variables (Karasar, 2005). The causal comparison is a type of research aiming to determine the causes of an existing situation or event, variables affecting these causes or the results of a cause (Buyukozturk, Cakmak, Akgun, Karadeniz and Demirel, 2008).

\section{Study Group}

The universe of the current research is comprised of the Education Faculty students of Mugla Sitki Kocman University and the sampling consists of fourth-year students selected through convenience sampling, one of the purposive sampling methods (Yildirim and Simsek, 2011). A total of 391 pre-service teachers from the departments of social studies, Turkish, classroom, pre-school, science and technology, music, arts, English, guidance and psychological counseling, elementary school mathematics and German participated in the study on a volunteer basis.

\section{Data Collection Tools}

The data in the current study were collected with the $21^{\text {st }}$ century learner skills use scale and the $21^{\text {st }}$ century teacher skills use scale. Moreover, a personal information form developed by the researcher to collect demographics of the participants was used.

1) The $21^{\text {st }}$ Century Learner Skills Use Scale: In the current study, the $21^{\text {st }}$ century learner skills use scale developed by Orhan-Goksun (2016) was used. The scale is made up of four factors that are cognitive skills, autonomous skills, collaboration and flexibility skills and innovativeness skills and 31 items. The total variance explained by the factors is $34.75 \%$ and the internal consistency coefficient was found to be .89 . The highest score to be taken from the $21^{\text {st }}$ century learner skills use scale is $155(31 \times 5=155)$ and the lowest score to be taken is $31(31 \times 1=31)$. The scale is in the form of five-point Likert scale with the response options; "never (1), rarely (2), sometimes (3), usually (4), always (5)".

2) The $21^{\text {st }}$ Century Teacher Skills Use Scale: In the current study, the $21^{\text {st }}$ century teacher skills use scale developed by Orhan-Goksun (2016) was used. The scale is comprised of a total of 27 items subsumed under five factors that are administrative skills, technopedagogical skills, affirmative skills, flexible teaching skills and generative skills. The total variance explained by these five factors is $40.33 \%$ and the internal consistency coefficient calculated for the scale is .87. The $23^{\text {rd }}$ item of the scale (I warn my students during the lesson) is reverse coded. The highest score to be taken from the $21^{\text {st }}$ century teacher skills use scale is $135(27 \times 5=135)$ and the lowest score to be taken is $27(27 \times 1=27)$. The scale is a five-point Likert scale with the response options; "never (1), rarely (2), sometimes (3), usually (4), always (5)".

The scales were administered in the spring term of 2017-2018 academic year. Cronbach Alpha coefficients calculated for the $21^{\text {st }}$ century learner skills use scale and the $21^{\text {st }}$ century teacher skills use scale and their sub-dimensions are given in Table 1.

Table 1. Internal Consistency Reliability Coefficients for the Scales and their Sub-dimensions

\begin{tabular}{lcc}
\hline Dimensions & Current Research & Orhan-Goksun (2016) \\
\hline Cognitive skills & 0,74 & 0,87 \\
Autonomous skills & 0,74 & 0,7 \\
Collaboration and flexibility skills & 0,74 & 0,67 \\
Innovativeness skills & 0,77 & 0,81 \\
Learner skills (Total) & 0,79 & 0,89 \\
Administrative skills & 0,65 & 0,85 \\
Technopedagogical skills & 0,68 & 0,62 \\
Affirmative skills & 0,72 & 0,41 \\
Flexible teaching skills & 0,8 & 0,75 \\
Generative skills & 0,67 & 0,71 \\
Teacher skills (Total) & 0,74 & 0,87 \\
\hline
\end{tabular}


3. Personal Information Form: In this form developed by the researcher, there are questions aiming to elicit information about the participants such as their gender, department, academic achievement, experience of private tutoring, experience of using learner skills and teacher skills during practicum teaching.

Data Analysis: The quantitative data collected through the $21^{\text {st }}$ century learner skills use scale and the $21^{\text {st }}$ century teacher skills use scale was analyzed. In the analysis of the data, Frequencies, Percentages, Arithmetic Means, Correlation Coefficients, Independent Samples t-Test, One-Way Variance Analysis, Mann Whitney-U test and Kruskal Wallis test were used (Buyukozturk, 2007).

\section{Findings / Results}

In this section, the findings are presented under the sub-problems. The findings related to the first sub-problem: the descriptive findings related to the pre-service teachers' gender, department, experience of private tutoring, academic achievement, experience of using learner skills and teacher skills during practicum teaching are presented in Table 2 .

Table 2. Frequencies and Percentages Related to the Pre-Service Teachers' General Demographics

\begin{tabular}{|c|c|c|c|}
\hline \multirow{4}{*}{ Gender } & & f & $\%$ \\
\hline & Female & 275 & 70.3 \\
\hline & Male & 116 & 29.7 \\
\hline & Total & 391 & 100 \\
\hline \multirow{12}{*}{ Department (branch) } & Turkish & 48 & 12.3 \\
\hline & Pre-school & 41 & 10.5 \\
\hline & Arts & 12 & 3.1 \\
\hline & Elementary school mathematics & 30 & 3.8 \\
\hline & Music & 12 & 9.0 \\
\hline & German & 15 & 11.5 \\
\hline & English & 35 & 13.6 \\
\hline & Classroom & 45 & 11.5 \\
\hline & Science and technology & 53 & 13.6 \\
\hline & Social studies & 41 & 10.5 \\
\hline & $\begin{array}{l}\text { Guidance and psychological } \\
\text { counseling }\end{array}$ & 59 & 15.1 \\
\hline & Total & 391 & 100 \\
\hline \multirow{3}{*}{ Experience of private tutoring } & Yes & 62 & 15.9 \\
\hline & No & 327 & 83.6 \\
\hline & Total & 391 & 100 \\
\hline \multirow{5}{*}{ Academic achievement } & Lower than 2.00 & 89 & 22.8 \\
\hline & Between 2.01 and 3.00 & 213 & 54.5 \\
\hline & Between 3.01 and 3.50 & 76 & 19.4 \\
\hline & Between 3.51 and 4.00 & 13 & 3.3 \\
\hline & Total & 391 & 100 \\
\hline \multirow{4}{*}{$\begin{array}{l}\text { Experience of using learner skills } \\
\text { during practicum teaching }\end{array}$} & I am lacking & 100 & 25.6 \\
\hline & Acceptable & 201 & 51.4 \\
\hline & Well-qualified & 90 & 23.0 \\
\hline & Total & 391 & 100 \\
\hline \multirow{4}{*}{$\begin{array}{l}\text { Experience of using teacher skills } \\
\text { during practicum teaching }\end{array}$} & I am lacking & 104 & 26.6 \\
\hline & Acceptable & 220 & 53.7 \\
\hline & Well-qualified & 77 & 22.8 \\
\hline & Total & 391 & 100 \\
\hline
\end{tabular}

As can be seen in Table 2, of the participating pre-service teachers, $70.3 \%$ are females and $29.7 \%$ are males; $12.3 \%$ are from the department of Turkish teaching, 10.5\% are from the department of pre-school teacher education, $3.1 \%$ are from the department of arts, 3.8\% are from the department of elementary school mathematics, $9.0 \%$ are from the department of music, $11.5 \%$ are from the department of German teaching, $13.6 \%$ are from the department of English teaching, $11.5 \%$ are from the department of classroom teacher education, $13.6 \%$ are from the department of science and technology teaching, $10.5 \%$ are from the department of social studies, $15.1 \%$ are from the department of guidance and psychological counseling; $15.9 \%$ of them have the experience of private tutoring and $83.6 \%$ do not have the experience of private tutoring; $22.8 \%$ have the grade point average lower than $2.00,54.5 \%$ have the grade point average between 2.01 and 3.00, 19.4\% have the grade point average between 3.01 and 3.50 and $3.3 \%$ have the grade point average between 3.51 and $4.00 ; 25.6 \%$ of the pre-service teachers think that they are lacking in relation to the experience of using learner skills during practicum teaching, 51.4\% think that they are acceptable and $23 \%$ think that 
they are well-qualified; $26.6 \%$ of the pre-service teachers think that they are lacking in relation to the experience of using teacher skills, $53.7 \%$ think that they are acceptable and $22.8 \%$ think that they are well-qualified.

The findings obtained from the gender-based comparison of the pre-service teachers' opinions about $21^{\text {st }}$ century learner and $21^{\text {st }}$ century teacher skills are given in Table 3.

Table 3. Gender-based Comparison of the Pre-Service Teachers' Opinions about $21^{\text {st }}$ Century Learner Skills and $21^{\text {st }}$ Century Teacher Skills

\begin{tabular}{|c|c|c|c|c|c|c|c|}
\hline Dimensions & Gender & $\mathbf{n}$ & $\overline{\mathbf{X}}$ & $\mathbf{S}$ & Sd & $\mathbf{t}$ & $\mathbf{p}$ \\
\hline \multirow{2}{*}{ Cognitive skills } & Male & 116 & 4,049 & ,533 & \multirow{2}{*}{389} & \multirow{2}{*}{2,486} & \multirow{2}{*}{0,01} \\
\hline & Female & 275 & 4,184 &, 471 & & & \\
\hline \multirow{2}{*}{ Autonomous skills } & Male & 116 & 3,696 & ,643 & \multirow{2}{*}{389} & \multirow{2}{*}{, 453} & \multirow{2}{*}{0,65} \\
\hline & Female & 275 & 3,727 & ,591 & & & \\
\hline \multirow{2}{*}{ Collaboration and flexibility skills } & Male & 116 & 3,395 & ,589 & \multirow{2}{*}{389} & \multirow{2}{*}{2,256} & \multirow{2}{*}{0,02} \\
\hline & Female & 275 & 3,556 & ,667 & & & \\
\hline \multirow{2}{*}{ Innovativeness skills } & Male & 116 & 3,905 & ,836 & \multirow{2}{*}{389} & \multirow{2}{*}{,790 } & \multirow{2}{*}{0,43} \\
\hline & Female & 275 & 3,976 & ,805 & & & \\
\hline \multirow{2}{*}{ Administrative skills } & Male & 116 & 3,928 & ,546 & \multirow{2}{*}{389} & \multirow{2}{*}{2,782} & \multirow{2}{*}{0,00} \\
\hline & Female & 275 & 4,091 &, 521 & & & \\
\hline \multirow{2}{*}{ Technopedagogical skills } & Male & 116 & 3,634 & ,471 & \multirow{2}{*}{389} & \multirow{2}{*}{2,200} & \multirow{2}{*}{0,02} \\
\hline & Female & 275 & 4,091 &, 522 & & & \\
\hline \multirow{2}{*}{ Affirmative skills } & Male & 116 & 4,413 & ,595 & \multirow{2}{*}{389} & \multirow{2}{*}{3,638} & \multirow{2}{*}{0,00} \\
\hline & Female & 275 & 4,624 & ,488 & & & \\
\hline \multirow{2}{*}{ Flexible teaching skills } & Male & 116 & 3,319 & 1,139 & \multirow{2}{*}{389} & \multirow{2}{*}{2,107} & \multirow{2}{*}{0,27} \\
\hline & Female & 275 & 3,454 & 1,108 & & & \\
\hline \multirow{2}{*}{ Generative skills } & Male & 116 & 3,745 & ,873 & \multirow{2}{*}{389} & \multirow{2}{*}{3,190} & \multirow{2}{*}{0,00} \\
\hline & Female & 275 & 4,076 & ,801 & & & \\
\hline
\end{tabular}

$\mathrm{p}<0.05$

As can be seen in Table 3, the female participants have better learner and teacher skills in the sub-dimensions of "collaboration and flexibility skills" (Male, $\overline{\mathrm{X}}=3.39$; Female, $\overline{\mathrm{X}}=3.55$ ), "administrative skills" (Male, $\overline{\mathrm{X}}=3.92 ; \mathrm{Female}, \overline{\mathrm{X}}=$ 4.09), "technopedagogical skills" (Male, $\bar{X}=3.63$; Female, $\bar{X}=4.09$ ), "generative skills" (Male, $\bar{X}=3.74 ;$ Female, $\bar{X}=4.07$ ). No significant gender-based difference was found in relation to "autonomous skills", "innovativeness skills" and "flexible teaching skills". However, Levene F test was used to investigate whether there is a gender-based significant difference for the sub-dimensions of "cognitive skills" and "affirmative skills". As the group variances are not equal, Mann Whitney$\mathrm{U}$ test was used to analyze. The obtained findings are presented in Table 4.

Table 4. Mann Whitney-U Test Results for the Pre-Service Teachers' $21^{\text {st }}$ Century Learner Skills and $21^{\text {st }}$ Century Teacher Skills According to the Gender Variable

\begin{tabular}{llccccc}
\hline Dimensions & Gender & N & Mean Rank & Rank Sum & M.W.U & p \\
\hline \multirow{2}{*}{ Cognitive Skills } & Female & 275 & 202,80 & 55769,00 & 14081,00 & 0,06 \\
& Male & 116 & 179,89 & 20867,00 & & \\
\hline \multirow{2}{*}{ Affirmative Skills } & Female & 275 & 208,74 & 54269,50 & 12445,500 & 0,00 \\
& Male & 116 & 165,81 & 22366,50 & & \\
\hline
\end{tabular}

$$
\mathrm{p}<0.05
$$

As can be seen in Table 4, a significant gender-based difference is seen in the sub-dimension of "affirmative skills". In the sub-dimension of "affirmative skills", the female pre-service teachers have a skills mean score (SO=208.74) higher than that of the male pre-service teachers $(\mathrm{SO}=165.81)$. On the other hand, no gender-based significant difference was found in the sub-dimension of "cognitive skills".

The findings obtained from the comparison of the pre-service teachers' $21^{\text {st }}$ century learner skills and $21^{\text {st }}$ century teacher skills on the basis of the department variable are given in Table 5. 
Table 5. Results of the Department-based Variance Analysis of the Pre-Service Teachers' $21^{\text {st }}$ Century Learner Skills and $21^{\text {st }}$ Century Teacher Skills

\begin{tabular}{|c|c|c|c|c|c|c|}
\hline Dimensions & Source of Variance & $\begin{array}{l}\text { Sum of } \\
\text { Squares }\end{array}$ & Sd & $\begin{array}{l}\text { Mean } \\
\text { Square }\end{array}$ & $\mathbf{F}$ & $\mathbf{p}$ \\
\hline \multirow[t]{3}{*}{ Cognitive skills } & Between-groups & 4,343 & 10 & ,434 & \multirow{3}{*}{1,819} & \multirow{3}{*}{0,05} \\
\hline & Within-groups & 90,726 & 380 & ,239 & & \\
\hline & Total & 95,068 & 390 & & & \\
\hline \multirow{3}{*}{ Autonomous skills } & Between-groups & 9,610 & 10 & ,961 & \multirow{3}{*}{2,729} & \multirow{3}{*}{0,00} \\
\hline & Within-groups & 133,822 & 380 & 352 & & \\
\hline & Total & 143,432 & 390 & & & \\
\hline \multirow{3}{*}{$\begin{array}{l}\text { Collaboration and } \\
\text { flexibility skills }\end{array}$} & Between-groups & 17,232 & 10 & 1,723 & \multirow{3}{*}{4,452} & \multirow{3}{*}{0,00} \\
\hline & Within-groups & 147,072 & 380 & ,387 & & \\
\hline & Total & 164,305 & 390 & & & \\
\hline \multirow{3}{*}{ Innovativeness skills } & Between-groups & 9,918 & 10 & & \multirow{3}{*}{1,516} & \multirow{3}{*}{0,13} \\
\hline & Within-groups & 248,548 & 380 & ,992 & & \\
\hline & Total & 258,467 & 390 & & & \\
\hline \multirow{3}{*}{ Administrative skills } & Between-groups & 4,347 & 10 & ,435 & \multirow{3}{*}{1,548} & \multirow{3}{*}{0,12} \\
\hline & Within-groups & 106,705 & 380 & 281 & & \\
\hline & Total & 111,053 & 390 & & & \\
\hline \multirow{3}{*}{ Technopedagogical skills } & Between-groups & 6,572 & 10 & ,657 & \multirow{3}{*}{2,625} & \multirow{3}{*}{0,00} \\
\hline & Within-groups & 95,149 & 380 & 250 & & \\
\hline & Total & 101,721 & 390 & & & \\
\hline \multirow{3}{*}{ Affirmative skills } & Between-groups & 5,122 & 10 &, 512 & \multirow{3}{*}{1,859} & \multirow{3}{*}{0,04} \\
\hline & Within-groups & 104,690 & 380 & 276 & & \\
\hline & Total & 109,812 & 390 & & & \\
\hline \multirow{3}{*}{ Flexible teaching skills } & Between-groups & 33,837 & 10 & 3,384 & \multirow{3}{*}{2,835} & \multirow{3}{*}{0,00} \\
\hline & Within-groups & 453,543 & 380 & 1,194 & & \\
\hline & Total & 487,380 & 390 & & & \\
\hline \multirow{3}{*}{ Generative skills } & Between-groups & 17,693 & 10 & 1,769 & \multirow{3}{*}{2,638} & \multirow{3}{*}{$0,0 c$} \\
\hline & Within-groups & 254,873 & 380 & 671 & & \\
\hline & Total & 272,565 & 390 & & & \\
\hline
\end{tabular}

$\mathrm{p}<0.05$

As can be seen in Table 5, the pre-service teachers' scores for $21^{\text {st }}$ century learner skills and $21^{\text {st }}$ century teacher skills vary significantly depending on the department variable in the sub-dimensions of "autonomous skills", "collaboration and flexibility skills", "technopedagogical skills", "affirmative skills", "flexible teaching skills" and "generative skills". In order to find the source of the difference between the groups of different departments, Scheffe test was administered. Yet, as a result of this test, no significant difference was found between the mean scores of the students from different departments. Moreover, no significant difference was found for the sub-dimensions of "cognitive skills", "innovativeness skills" and "administrative skills". Levene F test was also conducted to determine whether the mean scores of the preservice teachers from different departments vary significantly depending on the department variable. As the betweengroups variances were not found to be equal, Kruskal Wallis analysis was conducted. The obtained findings are presented in Table 6 . 
Table 6. The Results of Kruskal Wallis Test Conducted to Test Whether the Pre-Service Teachers' $21^{\text {st }}$ Learner Skills and $21^{\text {st }}$ Century Teacher Skills Vary Significantly Depending on the Department Variable

\begin{tabular}{|c|c|c|c|c|c|c|c|}
\hline Dimensions & Department & $\mathbf{N}$ & $\begin{array}{l}\text { Mean } \\
\text { Rank }\end{array}$ & sd & $\begin{array}{c}\text { Chi- } \\
\text { square }\end{array}$ & $\mathbf{p}$ & Significant difference \\
\hline \multirow{11}{*}{$\begin{array}{l}\text { Affirmative } \\
\text { skills }\end{array}$} & Turkish & 48 & 209,26 & \multirow[t]{11}{*}{10} & \multirow[t]{11}{*}{20,789} & \multirow[t]{11}{*}{0,02} & Arts $>$ Science-technology> \\
\hline & Pre-school & 41 & 180,57 & & & & Social studies $>$ \\
\hline & Arts & 12 & 250,17 & & & & Turkish> \\
\hline & Elementary math & 30 & 166,72 & & & & English> \\
\hline & Music & 12 & 140,88 & & & & Classroom> \\
\hline & German & 15 & 187,80 & & & & German> \\
\hline & English & 35 & 200,46 & & & & Pre-school> \\
\hline & Classroom & 45 & 195,24 & & & & Guidance and psychological \\
\hline & Science technology Social studies & 53 & 231,67 & & & & counseling > Elementary \\
\hline & Guidance and psychological & 41 & 211,70 & & & & math>Music \\
\hline & counseling & 59 & 168,08 & & & & \\
\hline
\end{tabular}

$\mathrm{p}<0.05$

As can be seen in Table 6, the pre-service teachers' $21^{\text {st }}$ century skills mean scores vary significantly depending on the department variable in the sub-dimension of "affirmative skills" $\left[\mathrm{X}^{2}(10)=20.789, \mathrm{p}<0.05\right]$. When the mean ranks of the groups are considered, it is seen that the highest mean score belongs to the students from the department of arts ( $\mathrm{SO}=250.17$ ) in the sub-dimension of "affirmative skills". They are followed by the students from the department of science and technology ( $\mathrm{SO}=231.67)$, the students from the department of social studies $(\mathrm{SO}=211.70)$, the students from the department of Turkish $(\mathrm{SO}=209.26)$, the students from the department of English $(\mathrm{SO}=200.46)$, the students from the department of classroom teacher education $(\mathrm{SO}=195.24)$, the students from the department of German ( $\mathrm{SO}=187.80)$, the students from the department of pre-school teacher education $(\mathrm{SO}=180.57)$, the students from the department of guidance and psychological counseling $(\mathrm{SO}=168.08)$, the students from the department of elementary school math teaching $(\mathrm{SO}=166.72)$ and the students from the department of music ( $\mathrm{SO}=140.88$.

The findings obtained from the academic achievement-based comparison of the pre-service teachers' $21^{\text {st }}$ century learner and $21^{\text {st }}$ century teacher skills are presented in Table 7.

Table 7. The Results of the Variance Analysis Conducted to Test Whether the Pre-Service Teachers' $21^{\text {st }}$ Century Learner Skills and $21^{\text {st }}$ Century Teacher Skills Scores Vary Significantly Depending on the Academic Achievement Variable

\begin{tabular}{|c|c|c|c|c|c|c|}
\hline Dimensions & Source of Variance & $\begin{array}{l}\text { Sum of } \\
\text { Squares }\end{array}$ & $\mathrm{Sd}$ & $\begin{array}{c}\text { Mean } \\
\text { Square }\end{array}$ & $\mathrm{F}$ & $\mathrm{p}$ \\
\hline \multirow[t]{3}{*}{ Cognitive skills } & Between-groups & 2,707 & 3 & 0,902 & & \multirow{3}{*}{0,01} \\
\hline & Within-groups & 92,361 & 387 & 0,239 & 3,781 & \\
\hline & Total & 95,068 & 390 & & & \\
\hline \multirow{3}{*}{ Autonomous skills } & Between-groups & 0,290 & 3 & 0,097 & & \multirow{3}{*}{0,85} \\
\hline & Within-groups & 143,142 & 387 & 0,370 & 0,262 & \\
\hline & Total & 143,432 & 390 & & & \\
\hline \multirow{3}{*}{$\begin{array}{l}\text { Collaboration and flexibility } \\
\text { skills }\end{array}$} & Between-groups & 1,380 & 3 & 0,460 & & \multirow{3}{*}{0,35} \\
\hline & Within-groups & 162,925 & 387 & 0,421 & 1,093 & \\
\hline & Total & 164,305 & 390 & & & \\
\hline \multirow{3}{*}{ Innovativeness skills } & Between-groups & 1,788 & 3 & \multirow{3}{*}{$\begin{array}{l}0,596 \\
0,663\end{array}$} & \multirow{3}{*}{0,899} & \multirow{3}{*}{0,44} \\
\hline & Within-groups & 256,679 & 387 & & & \\
\hline & Total & 258,467 & 390 & & & \\
\hline \multirow{3}{*}{ Administrative skills } & Between-groups & 2,149 & 3 & 0,716 & & \multirow{3}{*}{0,05} \\
\hline & Within-groups & 108,904 & 387 & 0,281 & 2,545 & \\
\hline & Total & 11,053 & 390 & & & \\
\hline \multirow{3}{*}{ Technopedagogical skills } & Between-groups & 0,722 & 3 & 0,241 & & \multirow{3}{*}{0,43} \\
\hline & Within-groups & 100,999 & 387 & 0,261 & 0,922 & \\
\hline & Total & 101,812 & 390 & & & \\
\hline \multirow{3}{*}{ Affirmative skills } & Between-groups & 5,001 & 3 & 1,667 & & \multirow{3}{*}{0,00} \\
\hline & Within-groups & 104,811 & 387 & 0,271 & 6,155 & \\
\hline & Total & 109,812 & 390 & & & \\
\hline \multirow{3}{*}{ Flexible teaching skills } & Between-groups & 0,801 & 3 & 0,267 & & \multirow{3}{*}{0,88} \\
\hline & Within-groups & 486,579 & 387 & 1,257 & 0,212 & \\
\hline & Total & 487,380 & 390 & & & \\
\hline \multirow{3}{*}{ Generative skills } & Between-groups & 6,045 & 3 & 2,015 & & \multirow{3}{*}{0,03} \\
\hline & Within-groups & 266,521 & 387 & 0,689 & 2,926 & \\
\hline & Total & 272,565 & 390 & & & \\
\hline
\end{tabular}

$\mathrm{p}<0.05$ 
As can be seen in Table 7, the pre-service teachers' $21^{\text {st }}$ century learner skills and $21^{\text {st }}$ century teacher skills scores vary significantly depending on the academic achievement variables in the sub-dimensions of "cognitive skills", "affirmative skills" and "generative skills". In order to find the source of the between-groups difference, Sheffe test was conducted. The results of Scheffe test revealed that the pre-service teachers with a grade point average lower than $2.00(\bar{X}=3.99)$ need more learner skills than the pre-service teachers with a grade point average between 3.01 and 3.50 in terms of the learner skills' sub-dimension of "cognitive skills". Moreover, it was found that the pre-service teachers with a grade point average lower than $2.00(\overline{\mathrm{X}}=3.77)$ need more teacher skills than the pre-service teachers with a grade point average between 3.51 and $4.00(\overline{\mathrm{X}}=4.34)$ in terms of teacher skills' sub-dimension of "generative skills".

No significant difference was found for the other sub-dimensions. In order to determine whether the pre-service teachers' "affirmative skills" vary significantly depending on the academic achievement variable, Levene F test was run. As the group's variances were not found to be equal, Kruskal Wallis analysis was conducted. The obtained findings are presented in Table 8.

Table 8. The Results of Kruskal Wallis Test Conducted to Determine Whether the Pre-Service Teachers' $21^{\text {st }}$ Century Learner Skills and $21^{\text {st }}$ Century Teacher Skills Scores Depending on the Academic Achievement Variable

\begin{tabular}{|c|c|c|c|c|c|c|c|}
\hline Dimensions & Academic Achievement & $\mathrm{N}$ & Mean Rank & $\mathrm{Sd}$ & Chi-square & $\mathrm{p}$ & $\begin{array}{l}\text { Significant } \\
\text { difference }\end{array}$ \\
\hline \multirow{4}{*}{$\begin{array}{l}\text { Affirmative } \\
\text { skills }\end{array}$} & (A) lower than 2 & 89 & 167,72 & \multirow[t]{4}{*}{3} & \multirow[t]{4}{*}{11.447} & \multirow[t]{4}{*}{0,01} & C-A, C-B, \\
\hline & (B) between 2.1 and 3 & 213 & 196,92 & & & & C-D, D-A, \\
\hline & (C) between 3.1. and 3.5 & 76 & 223,41 & & & & D-B, B-A \\
\hline & (D) between 3.51 and 4 & 13 & 214,23 & & & & \\
\hline
\end{tabular}

As can be seen in Table 8, the pre-service teachers' $21^{\text {st }}$ century teacher skills scores vary significantly depending on the academic achievement variable in the sub-dimension of "affirmative skills $\left[\mathrm{X}^{2}(3)=11.447\right.$, $\left.\mathrm{p}<0.05\right]$. When the betweengroups means are considered, it is seen that the pre-service teachers with a grade point average between 3.01 and 3.50 have the highest "affirmative skills" mean score ( $\mathrm{SO}=223.41)$. The pre-service teachers with a grade point average lower than 2.00 have a low "affirmative skills" mean score (SO=167.72).

The findings obtained from the comparison of the pre-service teachers' $21^{\text {st }}$ century learner and $21^{\text {st }}$ century teacher skills on the basis of experience of private tutoring are given in Table 9.

Table 9. The Results of t-Test Conducted to Determine Whether the Pre-Service Teachers' $21^{\text {st }}$ Century Learner Skills and $21^{\text {st }}$ Century Teacher Skills Scores Vary Significantly Depending on the Variable of Experience of Private Tutoring

\begin{tabular}{|c|c|c|c|c|c|c|c|}
\hline Dimensions & $\begin{array}{c}\text { Experience of } \\
\text { private tutoring }\end{array}$ & $\mathbf{N}$ & $\overline{\mathbf{X}}$ & $\mathbf{S}$ & Sd & $\mathbf{t}$ & $\mathbf{p}$ \\
\hline \multirow{2}{*}{ Cognitive skills } & Yes & 62 & 4,240 & ,549 & \multirow{2}{*}{389} & \multirow{2}{*}{1,671} & \multirow{2}{*}{0,09} \\
\hline & No & 329 & 4,126 & ,481 & & & \\
\hline \multirow{2}{*}{ Autonomous skills } & Yes & 62 & 3,876 & ,571 & \multirow{2}{*}{389} & \multirow{2}{*}{2,249} & \multirow{2}{*}{0,02} \\
\hline & No & 329 & 3,688 & 609 & & & \\
\hline \multirow{2}{*}{ Collaboration and flexibility skills } & Yes & 62 & 3,672 & ,634 & \multirow{2}{*}{389} & \multirow{2}{*}{2,173} & \multirow{2}{*}{0,03} \\
\hline & No & 329 & 3,477 & ,648 & & & \\
\hline \multirow{2}{*}{ Innovativeness skills } & Yes & 62 & 4,064 & ,861 & \multirow{2}{*}{389} & \multirow{2}{*}{1,153} & \multirow{2}{*}{0,25} \\
\hline & No & 329 & 3,934 & ,804 & & & \\
\hline \multirow{2}{*}{ Administrative skills } & Yes & 62 & 4,041 & ,563 & \multirow{2}{*}{389} & \multirow{2}{*}{0,029} & \multirow{2}{*}{0,97} \\
\hline & No & 329 & 4,043 &, 528 & & & \\
\hline \multirow{2}{*}{ Technopedagogical skills } & Yes & 62 & 3,687 & ,561 & \multirow{2}{*}{389} & \multirow{2}{*}{0,576} & \multirow{2}{*}{0,56} \\
\hline & No & 329 & 3,728 & ,501 & & & \\
\hline \multirow{2}{*}{ Affirmative skills } & Yes & 62 & 4,575 & 642 & \multirow{2}{*}{389} & \multirow{2}{*}{0,217} & \multirow{2}{*}{0,82} \\
\hline & No & 329 & 4,559 & ,508 & & & \\
\hline \multirow{2}{*}{ Flexible teaching skills } & Yes & 62 & 3,362 & 1,241 & \multirow{2}{*}{389} & \multirow{2}{*}{0,394} & \multirow{2}{*}{0,69} \\
\hline & No & 329 & 3,424 & 1,094 & & & \\
\hline \multirow{2}{*}{ Generative skills } & Yes & 62 & 4,096 & ,824 & \multirow{2}{*}{389} & \multirow{2}{*}{1,218} & \multirow{2}{*}{0,22} \\
\hline & No & 329 & 3,955 & ,837 & & & \\
\hline
\end{tabular}

$\mathrm{p}<0.05$

As can be seen in Table 9, the pre-service teachers' $21^{\text {st }}$ century learner skills scores vary significantly depending on the experience of private tutoring in the sub-dimensions of "autonomous skills" (having the experience, $\overline{\mathrm{X}}=3.87$; not having the experience, $\overline{\mathrm{X}}=3.68$ ) and "collaboration and flexibility skills" (having the experience, $\overline{\mathrm{X}}=3.67$; not having the experience $\bar{X}=3.47$ ) in favor of the pre-service teachers having the experience of private tutoring. No significant difference was found for the other learner and teacher skills sub-dimensions. 
Findings obtained from the comparison of the pre-service teachers' $21^{\text {st }}$ century learner and $21^{\text {st }}$ century teacher skills on the basis of their using learner skills during teaching practicum are given in Table 10.

Table 10. The Results of the Variance Analysis Conducted to Determine Whether the Pre-Service Teachers' 21 st Century Learner Skills and $21^{\text {st }}$ Century Teacher Skills Vary Significantly Depending on their Use of Learner Skills during Practicum Teaching

\begin{tabular}{|c|c|c|c|c|c|c|}
\hline Dimensions & $\begin{array}{l}\text { Source of } \\
\text { Variance }\end{array}$ & $\begin{array}{c}\text { Sum of } \\
\text { Squares }\end{array}$ & Sd & $\begin{array}{l}\text { Mean } \\
\text { Square }\end{array}$ & $\mathbf{F}$ & $\mathbf{p}$ \\
\hline Cognitive skills & $\begin{array}{l}\text { Between-groups } \\
\text { Within-groups } \\
\text { Total }\end{array}$ & $\begin{array}{c}5,786 \\
89,283 \\
95,068\end{array}$ & $\begin{array}{c}2 \\
388 \\
390 \\
\end{array}$ & $\begin{array}{c}2,893 \\
, 230\end{array}$ & 12,572 & 0,00 \\
\hline Autonomous skills & $\begin{array}{l}\text { Between-groups } \\
\text { Within-groups } \\
\text { Total }\end{array}$ & $\begin{array}{c}5,047 \\
138,385 \\
143,432 \\
\end{array}$ & $\begin{array}{c}2 \\
388 \\
390 \\
\end{array}$ & $\begin{array}{c}2,524 \\
, 357\end{array}$ & 7,075 & 0,00 \\
\hline $\begin{array}{l}\text { Collaboration and } \\
\text { flexibility skills }\end{array}$ & $\begin{array}{l}\text { Between-groups } \\
\text { Within-groups } \\
\text { Total }\end{array}$ & $\begin{array}{c}3,606 \\
160,698 \\
164,305\end{array}$ & $\begin{array}{c}2 \\
388 \\
390\end{array}$ & $\begin{array}{c}1,803 \\
, 414\end{array}$ & 4,354 & 0,01 \\
\hline Innovativeness skills & $\begin{array}{l}\text { Between-groups } \\
\text { Within-groups } \\
\text { Total }\end{array}$ & $\begin{array}{c}6,494 \\
251,973 \\
258,467\end{array}$ & $\begin{array}{c}2 \\
388 \\
390 \\
\end{array}$ & $\begin{array}{c}3,247 \\
, 649\end{array}$ & 5,000 & 0,00 \\
\hline Administrative skills & $\begin{array}{l}\text { Between-groups } \\
\text { Within-groups } \\
\text { Total }\end{array}$ & $\begin{array}{c}7,028 \\
251,973 \\
111,053\end{array}$ & $\begin{array}{c}2 \\
388 \\
390 \\
\end{array}$ & $\begin{array}{c}3,514 \\
, 268\end{array}$ & 13,107 & 0,00 \\
\hline Technopedagogical skills & $\begin{array}{l}\text { Between-groups } \\
\text { Within-groups } \\
\text { Total }\end{array}$ & $\begin{array}{c}2,944 \\
98,777 \\
101,721 \\
\end{array}$ & $\begin{array}{c}2 \\
388 \\
390 \\
\end{array}$ & $\begin{array}{c}1,472 \\
, 255\end{array}$ & 5,781 & 0,00 \\
\hline Affirmative skills & $\begin{array}{l}\text { Between-groups } \\
\text { Within-groups } \\
\text { Total }\end{array}$ & $\begin{array}{c}2,624 \\
107,188 \\
109,812\end{array}$ & $\begin{array}{c}2 \\
388 \\
390 \\
\end{array}$ & $\begin{array}{c}1,312 \\
, 276\end{array}$ & 4,749 & 0,00 \\
\hline Flexible learning skills & $\begin{array}{l}\text { Between-groups } \\
\text { Within-groups } \\
\text { Total }\end{array}$ & $\begin{array}{c}12,154 \\
475,226 \\
487,380\end{array}$ & $\begin{array}{c}2 \\
388 \\
390 \\
\end{array}$ & $\begin{array}{l}6,077 \\
1,225\end{array}$ & 4,961 & 0,00 \\
\hline Generative skills & $\begin{array}{l}\text { Between-groups } \\
\text { Within-groups } \\
\text { Total }\end{array}$ & $\begin{array}{c}9,764 \\
262,801 \\
272,565\end{array}$ & $\begin{array}{c}2 \\
388 \\
390\end{array}$ & $\begin{array}{c}4,882 \\
, 677\end{array}$ & 7,208 & 0,00 \\
\hline
\end{tabular}

As can be seen in Table 10, the pre-service teachers' $21^{\text {st }}$ century learner skills and $21^{\text {st }}$ century teacher skills scores vary significantly depending on the use of learner skills during practicum teaching in all the sub-dimensions. In order to find the source of the between-groups difference, Scheffe test was conducted. According to the results of Scheffe test, it can be said that the pre-service teachers see themselves better in terms of the use of learner skills when compared to teachers skills during practicum teaching in the sub-dimensions of "cognitive skills" (I am lacking, $\overline{\mathrm{X}}=3.96$; wellqualified, $\overline{\mathrm{X}}=4.30$ ), "autonomous skills" (I am lacking, $\overline{\mathrm{X}}=3.53$; well-qualified, $\overline{\mathrm{X}}=3.84$ ), "collaboration and flexibility skills" (I am lacking, $\overline{\mathrm{X}}=3,39$; well-qualified, $\overline{\mathrm{X}}=3.66)$, "innovativeness skills" (I am lacking, $\overline{\mathrm{X}}=3.80$; well-qualified, $\overline{\mathrm{X}}=4.10$ ), "administrative skills" (I am lacking, $\overline{\mathrm{X}}=3,85$; acceptable, $\overline{\mathrm{X}}=4,04$; well-qualified, $\overline{\mathrm{X}}=4.24$ ), "technopedagogical skills" (I am lacking, $\overline{\mathrm{X}}=3.60$; well-qualified, $\overline{\mathrm{X}}=3,85$ ), "affirmative skills" (I am lacking, $\overline{\mathrm{X}}=4.44$; well-qualified, $\overline{\mathrm{X}}=4.67$ ), "flexible teaching skills" (I am lacking, $\overline{\mathrm{X}}=3.20$; well-qualified, $\overline{\mathrm{X}}=3.70$ ), and "generative skills" (I am lacking, $\overline{\mathrm{X}}=3.79$; well-qualified, $\overline{\mathrm{X}}=4.23$ ).

Findings obtained from the comparison of the pre-service teachers' $21^{\text {st }}$ century learner and $21^{\text {st }}$ century teacher skills on the basis of their using teacher skills during teaching practicum are given in Table 11. 
Table 11. The Results of the Variance Analysis Conducted to Determine Whether the Pre-Service Teachers' $21^{\text {st }}$ Century Learner Skills and $21^{\text {st }}$ Century Teacher Skills Vary Significantly Depending on their Use of Teacher Skills during Practicum Teaching

\begin{tabular}{|c|c|c|c|c|c|c|}
\hline Dimensions & Source of Variance & $\begin{array}{l}\text { Sum of } \\
\text { Squares }\end{array}$ & Sd & $\begin{array}{l}\text { Mean } \\
\text { Square }\end{array}$ & $\mathbf{F}$ & $\mathbf{p}$ \\
\hline \multirow{3}{*}{ Cognitive skills } & Between-groups & 5,741 & 2 & \multirow{3}{*}{$\begin{array}{c}2,871 \\
, 230\end{array}$} & \multirow{3}{*}{12,469} & \multirow{3}{*}{0,00} \\
\hline & Within-groups & 89,327 & 388 & & & \\
\hline & Total & 95,068 & 390 & & & \\
\hline \multirow{3}{*}{ Autonomous skills } & Between-groups & 4,894 & 2 & 2,447 & \multirow{3}{*}{6,853} & \multirow{3}{*}{0,00} \\
\hline & Within-groups & 138,539 & 388 & ,357 & & \\
\hline & Total & 143,432 & 390 & & & \\
\hline \multirow{3}{*}{$\begin{array}{l}\text { Collaboration and flexibility } \\
\text { skills }\end{array}$} & Between-groups & 5,136 & 2 & \multirow{3}{*}{$\begin{array}{c}2,568 \\
, 410\end{array}$} & \multirow{3}{*}{6,260} & \multirow{3}{*}{0,00} \\
\hline & Within-groups & 159,169 & 388 & & & \\
\hline & Total & 164,305 & 390 & & & \\
\hline \multirow{3}{*}{ Innovativeness skills } & Between-groups & 3,511 & 2 & \multirow{3}{*}{$\begin{array}{l}1,756 \\
, 657\end{array}$} & \multirow{3}{*}{2,672} & \multirow{3}{*}{0,07} \\
\hline & Within-groups & 254,955 & 388 & & & \\
\hline & Total & 258,467 & 390 & & & \\
\hline \multirow{3}{*}{ Administrative skills } & Between-groups & 7,112 & 2 & 3,556 & \multirow{3}{*}{13,274} & \multirow{3}{*}{0,00} \\
\hline & Within-groups & 103,941 & 388 & ,268 & & \\
\hline & Total & 111,053 & 390 & & & \\
\hline \multirow{3}{*}{ Technopedagogical skills } & Between-groups & 4,191 & 2 & 2,095 & \multirow{3}{*}{8,336} & \multirow{3}{*}{0,00} \\
\hline & Within-groups & 97,530 & 388 & ,251 & & \\
\hline & Total & 101,721 & 390 & & & \\
\hline \multirow{3}{*}{ Affirmative skills } & Between-groups & 2,700 & 2 & 1,350 & \multirow{3}{*}{4,890} & \multirow{3}{*}{0,00} \\
\hline & Within-groups & 107,112 & 388 & ,276 & & \\
\hline & Total & 109,812 & 390 & & & \\
\hline \multirow{3}{*}{ Flexible learning skills } & Between-groups & 9,083 & 2 & 4,541 & \multirow{3}{*}{3,684} & \multirow{3}{*}{0,02} \\
\hline & Within-groups & 478,297 & 388 & 1,233 & & \\
\hline & Total & 487,380 & 390 & & & \\
\hline \multirow{3}{*}{ Generative skills } & Between-groups & 12,565 & 2 & 6,282 & \multirow{3}{*}{9,375} & \multirow{3}{*}{0,00} \\
\hline & Within-groups & 260,000 & 388 & ,670 & & \\
\hline & Total & 272,565 & 390 & & & \\
\hline
\end{tabular}

$$
\mathrm{p}<0.05
$$

As can be seen in Table 11, the pre-service teachers' $21^{\text {st }}$ century learner skills and $21^{\text {st }}$ century teacher skills scores vary significantly depending on the use of teacher skills during practicum teaching in some the sub-dimensions. In order to find the source of the between-groups difference, Scheffe test was conducted. According to the results of Scheffe test, it can be said that the pre-service teachers see themselves better in terms of the use of teachers skills when compared to learner skills during practicum teaching in the sub-dimensions of "cognitive skills" (I am lacking, $\overline{\mathrm{X}}=3.96$; well-qualified, $\overline{\mathrm{X}}=4.30$ ), “autonomous skills" (I am lacking, $\overline{\mathrm{X}}=3.54$; well-qualified, $\overline{\mathrm{X}}=3.80$ ), "collaboration and flexibility skills" (I am lacking, $\overline{\mathrm{X}}=3.32$; well-qualified, $\overline{\mathrm{X}}=3.60)$, "administrative skills" (I am lacking, $\overline{\mathrm{X}}=3.84 ;$ wellqualified, $\overline{\mathrm{X}}=4.23$ ), "technopedagogical skills" (I am lacking, $\overline{\mathrm{X}}=3.58$; well-qualified, $\overline{\mathrm{X}}=3.88$ ), "affirmative skills" (I am lacking, $\bar{X}=4.43$; well-qualified, $\bar{X}=4.67$ ), "flexible teaching skills" (I am lacking, $\bar{X}=3.18$; well-qualified, $\overline{\mathrm{X}}=3.61$ ) and "generative skills" (I am lacking, $\overline{\mathrm{X}}=3.72$; well-qualified, $\overline{\mathrm{X}}=4.28$ ). No significant difference was found in relation to the use of teacher skills during practicum teaching in the sub-dimension of "Innovativeness skills" (I am lacking, $\bar{X}=3.85$; well-qualified, $\bar{X}=4.12$ ).

Findings related to the second sub-problem: The results of the correlation analysis performed to determine the degree of the relationship between the pre-service teachers' $21^{\text {st }}$ century learner skills and $21^{\text {st }}$ century teacher skills scores are given in Table 12. 
Table 12. Correlations between the Pre-Service Teachers' $21^{\text {st }}$ Century Learner Skills and $21^{\text {st }}$ Century Teacher Skills Scores

\begin{tabular}{|c|c|c|c|c|c|c|c|c|c|c|c|}
\hline Dimensions & 1 & 2 & 3 & 4 & 5 & 6 & 7 & 8 & 9 & 10 & 11 \\
\hline 1.Cognitive & 1 & & & & & & & & & & \\
\hline 2.Autonomous & $.54^{* *}$ & 1 & & & & & & & & & \\
\hline 3.Collaboration & $.54^{* *}$ & $.53^{* *}$ & 1 & & & & & & & & \\
\hline and flexibility & & & & & & & & & & & \\
\hline 4.Innovativeness & $.53^{* *}$ & $.48^{* *}$ & $.48^{* *}$ & 1 & & & & & & & \\
\hline 5.Learner skills Total & $.90^{* *}$ & $.77^{* *}$ & $.77^{* *}$ & $.67^{* *}$ & 1 & & & & & & \\
\hline 6.Administrative & $.62^{* *}$ & $.36^{* *}$ & $.39^{* *}$ & $.39^{* *}$ & $.59^{* *}$ & 1 & & & & & \\
\hline 7.Teknopedagogical & $.52^{* *}$ & $.44^{* *}$ & $.45^{* *}$ & $.52^{* *}$ & $.58^{* *}$ & $.68^{* *}$ & 1 & & & & \\
\hline 8.Affirmative & $.58^{* *}$ & $.26^{* *}$ & $.21^{* *}$ & $.27^{* *}$ & $.47^{* *}$ & $.61^{* *}$ & $.42^{* *}$ & 1 & & & \\
\hline 9.Flexible teaching & $.24^{* *}$ & $.19^{* *}$ & $.35^{* *}$ & $.18^{* *}$ & $.30^{* *}$ & $.41^{* *}$ & $.38^{* *}$ & $.20^{* *}$ & 1 & & \\
\hline 10.Generative & $.44^{* *}$ & $.23^{* *}$ & $.35^{* *}$ & $.33^{* *}$ & $.44^{* *}$ & $.61^{* *}$ & $.50^{* *}$ & $.42^{* *}$ & $.35^{* *}$ & 1 & \\
\hline 11.Teacher skills & $.65^{* *}$ & $.41^{* *}$ & $.47^{* *}$ & $.46^{* *}$ & $.65^{* *}$ & $.93^{* *}$ & $.83^{* *}$ & $.65^{* *}$ & $.56^{* *}$ & $.70^{* *}$ & 1 \\
\hline
\end{tabular}

Correlation significant at ${ }^{* *} \mathrm{p}<0.01,{ }^{*} \mathrm{p}<0.05$

As can be seen in Table 12, a significant correlation was found between the pre-service teachers' $21^{\text {st }}$ century learner skills and $21^{\text {st }}$ century teacher skills total scores. This correlation is positive and medium $(r=0.65)$.

\section{Discussion and Conclusion}

In the current study, the aim was to determine the relationships between the pre-service teachers' use of $21^{\text {st }}$ century learner skills and $21^{\text {st }}$ century teacher skills. The pre-service teachers' use of $21^{\text {st }}$ century learner skills and $21^{\text {st }}$ century teacher skills vary significantly depending on the variables of gender, department, experience of private tutoring, use of learner skills during practicum teaching and use of teacher skills during practicum teaching.

When the pre-service teachers' use of $21^{\text {st }}$ century learner skills was investigated on the basis of the gender variable, it was found that the female pre-service teachers' "collaboration and flexibility skills" are better than that of the male preservice teachers. This finding may indicate that female pre-service teachers are more prone to working in teams and pay greater attention to collaboration than male pre-service teachers. In a study conducted by Yesilyurt (2010), no gender-based significant difference was found between the participating pre-service teachers' qualifications in terms of suitability for cooperation-based learning method. The reasons for the inconsistency between the finding of the current study and that of Yesilyurt (2010) may be because Yesilyurt's sampling is dominated by the students of Technical Education Faculty most of whose student population is made up of male students. In the research of Daghan et al. (2017), pre-service teachers stated that the learners of the $21^{\text {st }}$ century should have collaborative working skills. No significant difference was found depending on the gender variable in the sub-dimensions of "cognitive skills", "autonomous skills", "innovativeness skills" and "flexible teaching skills". When the pre-service teachers' use of $21^{\text {st }}$ teacher skills was investigated on the basis of the gender variable, it was found that the female pre-service teachers have higher use of "administrative skills", "technopedagogical skills", "generative skills", "affirmative skills". This might be because the female pre-service teachers have more positive attitudes towards the profession of teaching, they are more idealistic and they train themselves better. In the existing research, female pre-service teachers' attitudes towards the profession of teaching have been found to be higher (Aksoy, 2010; Sahin and Sahin, 2017; Ustuner, Demirtas and Comert, 2009). In a study by Orhan-Goksun (2016), the female pre-service teachers were found to have higher use of $21^{\text {st }}$ century teacher skills than the male pre-service teachers. The findings of this study concur with the findings of the current study. On the other hand, in a study conducted by Gurultu, Aslan and Alci (2018) to investigate the elementary school teachers' use of $21^{\text {st }}$ century teacher skills on the basis of the gender variable, a significant difference was found only for "flexible teaching skills" in favor of the male teachers. This study does not support the findings of the current study.

When the pre-service teachers' $21^{\text {st }}$ century learner skills were investigated on the basis of the department variable, it was found that their "cognitive skills", "autonomous skills", "collaboration and flexibility skills", "innovativeness skills" vary significantly depending on the department variable. When the pre-service teachers' $21^{\text {st }}$ century teacher skills were investigated on the basis of the department variable, it was found that while their "administrative skills", "technopedagogical skills", "flexible teaching skills" and "generative skills" do not vary significantly depending on the department variable, "affirmative skills" vary significantly. 
In terms of "affirmative skills", the pre-service teachers from the department of arts see themselves better. In the study by Orhan-Goksun (2016), it was also found that the pre-service teachers most using $21^{\text {st }}$ teacher skills are those from the department of fine arts in Balikesir University. Coklar (2008) reported that depending on the department variable, the educational technology standards vary in relation to social, ethical, legal and humanitarian issues. The pre-service teachers from the departments of computer and instructional technologies and arts were found to be more adequate than the pre-service teachers from the other departments.

When the pre-service teachers' $21^{\text {st }}$ century learner skills were investigated on the basis of the academic achievement variable, it was found that their "cognitive skills" vary significantly depending on the academic achievement variable. It is seen that the pre-service teachers with a grade point average lower than 2.00 need more learner skills than the preservice teachers with a grade point average between 3.01 and 3.50. This finding shows that the pre-service teachers with lower academic achievement have inadequate awareness of the processing and coding of information through cognitive processes and of the outputs emerging as a result of the operations taking place in mental processes. Daghan et al., (2017) found that among 21 st century skills most strongly emphasized by the pre-service teachers come cognition-based skills to the fore. Doganay and Demir (2011) found that in all the dimensions of cognitive awareness, the cognitive awareness levels of the pre-service teachers having higher academic achievement were found be significantly higher than those of the pre-service teachers with lower academic achievement. Kana (2015) found that the pre-service Turkish teachers with a grade point average between 2.51 and 4.00 were found to be better at organizing the learning process than the pre-service Turkish teachers with a grade point average between 1.00 and 2.50. The findings of these studies concur with the findings of the current study. No significant difference was found in the other sub-dimensions.

When the pre-service teachers' $21^{\text {st }}$ century teacher skills were investigated on the basis of the academic achievement variable, it was found that their "generative skills" and "affirmative skills" vary significantly depending on the academic achievement variable. In terms of "generative skills", the pre-service teachers with a grade point average lower than 2.00 need more teacher skills than the pre-service teachers with a grade point average between 3.51 and 4.00 . This might be because of the difficulties experienced by the pre-service teachers with a lower grade point average in designing materials and using them in activities. These problems can be solved by teaching them how to develop versatile materials and how to use them in teaching-learning environment. The pre-service teachers with a grade point average between 3.01 and 3.50 were found to have the highest "affirmative skills". On the other hand, the pre-service teachers with a grade point average lower than 2.00 were found to have lower "affirmative skills". This finding can be explained by the assumption that the pre-service teachers with lower academic achievement may feel inadequate in terms of content knowledge and pedagogical knowledge. Torun and Karamustafaoglu (2017) conducted a study on preservice teachers from an education faculty and their mean content knowledge level was found to be $47.63 \%$. This shows that their content knowledge competence is quite low. According to OSYM (2018) Teaching Content Knowledge Test (OABT) 2017 report, the raw score means of the examinees from the subject area tests varied from 11.82 to 34.88. According to this report, new graduates can correctly answer only half of the questions related to their own subject area.

In a study by Sural (2017), it was found that the pre-service teachers having $21^{\text {st }}$ century skills also think that $21^{\text {st }}$ century skills are important. Therefore, the pre-service teachers with low academic achievement first need to believe the importance of $21^{\text {st }}$ century skills to acquire these skills. No significant difference was found in the other subdimensions.

When the pre-service teachers' $21^{\text {st }}$ century learner skills scores were investigated on the basis of the experience of private tutoring, it was found that the scores of the pre-service teachers with the experience of private tutoring taken from the sub-dimensions of "autonomous skills" and "collaboration and flexibility skills" are higher than those of the preservice teachers not having the experience of private tutoring. Teachers giving private tutoring find the opportunity of working with students from different age groups having different mental capacities and learning styles. Thus, they can see their weaknesses and strengths in terms of teaching skills. As a result, they can look for ways of enhancing their weaknesses. In a study conducted by Valtonen et al. (2017), the pre-service teachers were found to be viewing themselves as good at cooperation, team work and learning strategies. Sural (2017) reported that the pre-service teachers got the highest scores from the importance of life and career skills. This is followed by the importance of learning and innovativeness. The findings of these studies support the findings of the current study. No significant difference was found in the other learner and teacher sub-dimensions.

When the pre-service teachers' $21^{\text {st }}$ century learner skills and $21^{\text {st }}$ century teacher skills were investigated on the basis of using learner skills during practicum teaching, it was found that they vary significantly depending on using learner skills during practicum teaching in all the sub-dimensions. In this regard, it can be argued that the pre-service teachers trained themselves better at using learner skills in the sub-dimensions of "cognitive skills", "autonomous skills", "collaboration and flexibility skills", "innovativeness skills", "administrative skills","technopedagogical skills", "affirmative skills", "flexible teaching skills" and "generative skills" during practicum teaching when compared to teacher skills. The pre-service teachers use $21^{\text {st }}$ century learner skills in the process of planning, preparing and application of tools, materials and activities in the learning-teaching process. Thus, it can be argued that the pre-service teachers' using $21^{\text {st }}$ 
century learner skills during practicum teaching developed their learner skills. A pre-service teacher who is a good learner can also be a good teacher. Orhan-Goksun (2016) found that the pre-service teachers' use of learner skills is above the medium level. In addition, Cretu (2017) found that through practicum teaching, the pre-service teachers developed some of their $21^{\text {st }}$ century skills such as communication, critical thinking, collaboration and creative learning skills. The findings of these studies concur with the findings of the current study.

Gunuc, Odabası and Kuzu (2013) subsumed 21 st century learner characteristics under four main themes that are personal skills, research and information acquisition skills, creativity and career skills and technology skills. In a study by Daghan et al. (2017), the pre-service teachers defined themselves as individuals who can have access to information, are open to life-long learning, can think critically and creatively, have problem-solving skills, can establish effective communication, can use technology and have collaborative learning skills. The findings of these studies support the findings of the current study.

When the pre-service teachers' $21^{\text {st }}$ century learner skills and $21^{\text {st }}$ century teacher skills scores were investigated on the basis of their using teacher skills during practicum teaching, it was found that they vary significantly in all the subdimensions of learner skills. As for teacher skills, in only the sub-dimension of "innovativeness skills", no significant difference was found. This might be because of the presence of new technological tools and digital programs in many of the schools. Significant differences were found for the other sub-dimensions of teacher skills. Thus, it can be argued that the pre-service teachers trained themselves better at using teacher skills during practicum teaching in the subdimensions of "cognitive skills", "autonomous skills", "collaboration and flexibility skills", "administrative skills", "technopedagogical skills", "affirmative skills", "flexible teaching skills" and "generative skills". During practicum teaching, pre-service teachers prepare instructional activities and materials and deliver lessons through these activities and materials, resulting in their gaining teaching experience. The pre-service teachers can see their weaknesses and strengths in terms of teaching skills. The pre-service teachers' use of teacher skills promotes the development of their learner and teacher skills. A pre-service teacher with good teacher skills will probably continuously develop himself/herself as a learner. Orhan-Goksun (2016) determined that the pre-service teachers use $21^{\text {st }}$ century teacher skills above the medium level. Gurultu et al. (2018) found that the elementary school teachers' level of use of $21^{\text {st }}$ century teacher skills is high. In addition to this, in Tsourapa's study (2018), many of the teachers were found to have positive attitudes towards $21^{\text {st }}$ century skills. The findings of these studies concur with the findings of the current study. Daghan et al. (2017) found that the pre-service teachers pay great attention to $21^{\text {st }}$ century learner skills, have adequate information and skills needed to organize the learning environment, are continuously learning and developing themselves, can serve as a guide for students along their learning process and have strong subject area knowledge.

In the current study, a positive and medium correlation as found between the pre-service teachers' $21^{\text {st }}$ century learner skills and $21^{\text {st }}$ century teacher skills total scores $(r=0.65)$. Orhan-Goksun (2016) found significant and positive correlations between the sub-dimensions of $21^{\text {st }}$ century learner skills and $21^{\text {st }}$ century teacher skills.

As a result, the current study shows that the pre-service teachers accomplished learning outcomes in general complying with the $21^{\text {st }}$ century learner skills and the $21^{\text {st }}$ century teacher skills. The female pre-service teachers' use of the $21^{\text {st }}$ century learner skills in terms of collaboration and flexibility skills and use of the $21^{\text {st }}$ century teacher skills in terms of administrative skills, technopedagogical skills, generative skills and affirmative skills is higher than that of the male pre-service teachers. The pre-service teachers from the department of arts see themselves better than the preservice teachers from the other departments in terms of using the affirmative skills, a set of $21^{\text {st }}$ century teacher skills. The cognitive skills, a set of $21^{\text {st }}$ century learner skills, and the generative skills and affirmative skills, two sets of $21^{\text {st }}$ century teacher skills, of the pre-service teachers having a grade point lower than 2.00 were found to be relatively lower. The $21^{\text {st }}$ century learner skills mean score of the pre-service teachers having the experience of private tutoring was found to be higher than that of the pre-service not having the experience of private tutoring in relation to autonomous skills and flexibility skills. The $21^{\text {st }}$ century learner skills and $21^{\text {st }}$ century teacher skills mean scores of the pre-service teachers utilizing learner skills during their practicum teaching at schools were found to be higher in all the sub-dimensions. The use of the $21^{\text {st }}$ century learner skills was found to be higher for the pre-service teachers making use of the teacher skills during their practicum teaching in relation to cognitive skills, autonomous skills, collaboration and flexibility skills and their use of the $21^{\text {st }}$ century learner skills was found to be higher in relation to administrative skills, technopedagogical skills, affirmative skills, flexible teaching skills, generative skills. A positive and moderate correlation was found between the pre-service teachers' $21^{\text {st }}$ century learner and $21^{\text {st }}$ century teacher skills.

In light of the research findings, some suggestions can be made: Activities can be conducted to enhance the male preservice teachers' attitudes and motivation towards the profession of teaching so that their teacher skills can be fostered. In order to improve pre-service teachers' affirmative skills at education faculties, supplementary learning activities can be organized. Education faculties can be equipped with new technological tools such as smart boards, documentary cameras for pre-service teachers to make more effective and efficient use of the $21^{\text {st }}$ century learner skills. Faculty members working at education faculties carry out educational and instructional activities do develop preservice teachers' $21^{\text {st }}$ century learner and teacher skills. New research can be designed to elicit what these activities 
are. Elective course can be incorporated into the curriculums of education faculties related to the use of learner and teacher skills.

Experimental studies can be conducted to enhance pre-service teachers' $21^{\text {st }}$ learner and $21^{\text {st }}$ century teacher skills. The $21^{\text {st }}$ century learner skills and the $21^{\text {st }}$ century teacher skills of pre-service teachers attending different education faculties located across Turkey can be compared. The current study was conducted on senior students. Studies can be conducted focusing on different departments and grade levels.

The pre-service teachers participating in the current study have been educated according to the 2006 teacher training program. In 2018-2019 academic year, a new teacher training program was put into effect in the undergraduate programs. The $21^{\text {st }}$ learner skills and the $21^{\text {st }}$ century teacher skills of the pre-service teachers educated according to the new program can be investigated.

The $21^{\text {st }}$ century learner skills and $21^{\text {st }}$ century teacher skills of the teachers working in state schools of the Ministry of National Education in Turkey can be investigated in relation to various variables. In-service teacher training programs can be organized about the topics needed by teachers.

\section{References}

AASL (American Association of School Librarians). (2009). Standards for the 21st century learner in action. Chicago: ALA.

Aksoy, M. E. (2010). Pre-service teachers' attitudes towards the profession of teaching. Social Sciences Research Journal, 2, 197-212.

Akgunduz, D., Aydeniz, M., Cakmakcı, G., Cavas, B., Corlu, M. S., Oner, T., \& Ozdemir, S. (2015). STEM education Turkish report. Istanbul: Scala Basim.

Aydeniz, M. (2017, October). Our education system and our 21 ${ }^{\text {st }}$ century dream: An STEM-based economic route map for Turkey while we are progressing towards our goals. University of Tennessee, Knoxville. Retrieved from https://trace.tennessee.edu/cgi/viewcontent.cgi?referer=https://www.google.com.tr/\&httpsredir=1\&article=101 $9 \&$ context=utk_theopubs

Buyukozturk, S. (2007). A handbook for social sciences data analysis. Ankara: PegemA Yayincilik.

Buyukozturk, S., Cakmak, E. K., Akgun, O. E., Karadeniz, S., \& Demirel, F. (2008). Scientific research methods. Ankara: PegemA Yayincilik.

Cretu, D. (2017). Fostering 21st century skills for future teachers. The European Proceedings of Social \& Behavioural Sciences, 23, 672-681. doi: http://dx.doi.org/10.15405/epsbs.2017.05.02.82.

Coklar, A. N. (2008). Determination of pre-service teachers' self-efficacies in relation to education technology standards (Unpublished doctoral thesis). Anadolu University, Eskisehir, Turkey.

Daghan, G., Nuhoglu Kibar, P., Menzi Cetin, N., Telli, E., \& Akkoyunlu, B. (2017). 21 ${ }^{\text {st }}$ century learner and teacher characteristics from the perspectives of the pre-service information technologies pre-service teachers. Education Technology Theory and Practice, 7(2), 215-235. doi:10.17943/etku.305062.

Dede, C. (2009). Comparing frameworks for 21st century skills. Retrieved from http://citeseerx.ist.psu.edu/viewdoc/download?doi=10.1.1.475.3846\&rep=rep1\&type=pdf

Doganay, A., \& Demir, O. (2011). Comparison of the level of utilizing cognitive awareness skills of pre-service teachers with low and high academic achievement while revising. Educational Sciences in Theory and Practice, 11(4), 20112043.

Eryılmaz, S., \& Uluyol, C. (2015). Evaluation of the FATIH Project in light of $21^{\text {st }}$ century skills. GEFAD/GUJGEF, 35(2), 209-229.

Gunuc, S., Odabası, F., \& Kuzu, A. (2013). Definition of the $21^{\text {st }}$ century student characteristics by pre-service teachers: A Twitter application. Theory and Practice in Education, 9(4), 436-455.

Gurultu, E., Aslan, M., \& Alci, B. (2018). Investigation of elementary school teachers' competences in light of $21^{\text {st }}$ century skills. Academic Social Studies Journal, 6(71), 543-560.

Häkkinen, P., Järvelä, S., Mäkitalo-Siegl, K., Ahonen, A., Näykki, P., \& Valtonen, T. (2017). Preparing teacher-students for twenty-first-century learning practices (PREP 21): A framework for enhancing collaborative problem-solving and strategic learning skills. Teachers and Teaching: Theory and Practice, 23(1), 25-41. doi:10.1080/13540602.2016.1203772.

ISTE Standars-T. (2008). ISTE standards: Teachers. Retrieved from http://www.iste.org/docs/pdfs/2014_ISTE_Standards-T_PDF.pdf 
ISTE (International Society for Technology in Education). (2018). About ISTE. Retrieved from http://www.iste.org/about

Karasar, N. (2005). Scientific research methods. Ankara: Nobel Yayincilik.

Kana, F. (2015). Pre-service Turkish teachers' motivational, cognitive and metacognitive competences. International Educational Sciences Journal, 2(4), 395-407.

Lemov, D. (2010). Teach like a champion: 49 techniques that put students on the path to college (K-12). San Francisco, CA: John Wiley \& Sons.

Melvin, L. (2011). How to keep good teachers and principals: practical solutions to today's classroom problems. Lanham, MD: Rowman \& Littlefield Education.

MEB. (2017a). A study on curriculum renewal and change works. Retrieved from https://ttkb.meb.gov.tr/meb_iys_dosyalar/2017_07/18160003_basin_aciklamasi-program.pdf

MEB. (2017b). General competences of the profession of teaching. Retrieved from http://oygm.meb.gov.tr/meb_iys_dosyalar/2017_12/11115355_yyretmenlyk_mesleyy_genel_yeterlyklery.pdf

MEB. (2018). A study on FATIH project in education. Retrieved from http://fatihprojesi.meb.gov.tr/proje-hakkinda/

Orhan-Goksun, D. (2016). The relationship between pre-service teachers' $21^{\text {st }}$ century learner skills and $21^{\text {st }}$ century teacher skills (Unpublished doctoral thesis). Anatolian University, Eskisehir, Turkey.

Orhan-Goksun, D., \& Askım-Kurt, A. (2017). The relationship between pre-service teachers' use of $21^{\text {st }}$ century learner skills and use of $21^{\text {st }}$ century teacher skills. Education and Science, 42(190), 107-130. doi:10.15390/EB.2017.7089.

Orhan, D., Kurt, A. A., Ozan, S., Som Vural, S., \& Turkan, F. (2014). A general overview of national education technology standards. Karaelmas Journal of Educational Science, 2(1), 65-79.

OSYM. (2018). 2017 OABT evaluation report. Retrieved from https://dokuman.osym.gov.tr/pdfdokuman/2018/genel/2017_OABT_DRapor26072018.pdf

Partnership21 (P21). (2015). P21 framework definitions. Retrieved from http://www.p21.org/storage/documents/docs/P21_Framework_Definitions_New_Logo_2015.pdf

Pedro, F. (2006). The new millennium learners: Challenging our views on ICT and learning. Retrieved from http://www.oecd.org/edu/ceri/38358359.pdf

Saavedra, A., \& Opfer, D. (2012a). Teaching and learning 21st century skills: lessons from the learning sciences. New York: Asia Society.

Saavedra, A., \& Opfer, D. (2012b). Learning 21st-century skills requires 21st-century teaching. Phi Delta Kappan, 94(2), 8-13.

Schleicher, A. (Ed.). (2012). Preparing Teachers and Developing School Leaders for the 21st Century: Lessons from around the World. Paris: OECD Publishing.

Sural, I. (2017). 21st century skills level of teacher candidates. European Journal of Education Studies, 3(8), 530-538.

Sahin, M. C. (2010). Evaluation of education faculty students according to new millennium learners (OECD New millennium learners) standards (Unpublished doctoral thesis). Anatolian University, Eskisehir, Turkey.

Sahin, C., \& Sahin, S. (2017). Pre-service teachers' attitudes towards the profession of teaching, self-efficacy beliefs and level of knowing students. Turkish Educational Sciences Journal, 15(2), 224-238.

Torun, B., \& Karamustafaoglu, O. (2017). Determination of the pre-service science teachers' content knowledge. In 0. Demirel \& S. Dincer (Eds.), Education in the globalizing world (91-118). Ankara: PegemA Yayincilik.

Trilling, B., \& Fadel, C. (2009). 21st century skills: Learning for life in our times: learning for life in our times. San Francisco, CA: John Wiley \& Sons.

Tsourapa, A. (2018). Exploring teachers' attitudes towards the development of 21st century skills in EFL teaching. Research Papers in Language Teaching \& Learning, 9(1), 6-31.

Ustuner, M., Demirtas, H., \& Comert, M. (2009). Pre-service teachers' attitudes towards the profession of science. Education and Science Journal, 34(151), 140-155.

Valtonen, T., Sointu, E. T., Kukkonen, J., Häkkinen, P., Järvelä, S., Ahonen, A., \& et al. (2017). Insights into Finnish firstyear pre-service teachers' perceptions of their 21st century skills. Education and Information Technologies, 22(5), 2055-2069. 
Valli, P., Perkkilä, P., \& Valli, R. (2014). Adult preservice teachers: Applying 21st century skills in the practice. Athens Journal of Education, 1(2), 115-129.

Voogt, J., Erstad, O., Dede, C., \& Mishra, P. (2013). Challenges to learning and schooling in the digital networked world of the 21st century. Journal of Computer Assisted Learning, 29(5), 403-413.

Wagner, T. (2008). The global achievement gap: Why even our best schools don't teach the new survival skills our children need-and what we can do about it. New York: Basic Books.

Yesilyurt, E. (2010). Evaluation of the suitability of pre-service teachers' qualifications for the cooperation-based learning method. Dicle University Ziya Gokalp Education Faculty Journal, 14, 25-37.

Yildirim, A., \& Simsek, H. (2011). Research methods in social sciences. Ankara: Seckin Yayinevi.

YOK. (2018). Teacher training undergraduate programs. Retrieved from

http://www.yok.gov.tr/documents/10279/41805112/AA Sunus +Onsoz Uygulama Yonergesi.pdf 